\title{
CANINE HEARTWORM DISEASE IN A BRAZILIAN NON-ENDEMIC AREA
}

\author{
Marina Mitie Monobe ${ }^{1}$ \\ Rodrigo Costa da Silva ${ }^{1}$ \\ Mariana Serrano Melanchauski² \\ Raimundo Souza Lopes ${ }^{2}$
}

MONOBE, M. M.; SILVA, R. C. da; MELANCHAUSKI, M. S.; LOPES, R. S. Canine Heartworm Disease in a Brazilian non-endemic area. Arq. Ciênc. Vet. Zool. UNIPAR, Umuarama, v. 19, n. 2, p. 95-100, abr./jun. 2016.

\begin{abstract}
Canine Heartworm Disease (CHD) is a mosquito-borne disease caused by Dirofilaria immitis. In this study, two mature adult-senior dogs from a non-endemic area to CHD presented clinical signs suggestive to the disease. The first one presented skin lesions, loss of appetite, weakness, pale mucosa membrane, and hyperthermia, whereas the second one presented severe ascites, anorexia and exercise intolerance, lateral decumbency, and marked heart murmurs. Both presented tachypnea, thrombocytopenia, leukocytosis, and microfilaremia. Multiplex-PCR (COI gene) resulted positive to D. immitis research in both cases, confirmed by sequencing, with $98 \%$ homology to D. immitis (Gen Bank accession n.AJ537512-1). In addition, both animals have never had any prophylactic treatment to $\mathrm{CHD}$, and no reports about traveling to coastal areas. This study reported two unusual cases of D. immitis infection in non-endemic area from Brazil.
\end{abstract}

KEYWORDS: Dirofilaria immitis. Dog. Microfilariae. Molecular techniques. Parasitic nematode.

\section{DIROFILARIOSE CANINA EM UMA ARÉA NÃO ENDÊMICA BRASILEIRA}

RESUMO: A dirofilariose canina (CHD) é uma doença transmitida por mosquitos e causada por Dirofilaria immitis. No presente estudo, dois cães de idade adulta a idoso de área não endêmica apresentaram sinais clínicos sugestivos da doença. $\mathrm{O}$ primeiro apresentou lesões de pele, perda de apetite, fraqueza, mucosas pálidas e hipertermia, enquanto o segundo apresentou severo quadro de ascite, anorexia e intolerância ao exercício, decúbito lateral, e murmúrios cardíacos acentuados. Ambos apresentaram taquipneia, trombocitopenia, leucocitose e microfilaremia. A pesquisa por $D$. immitis pela multiplex-PCR (COI gene) resultou positiva em ambos os casos, confirmada pelo sequenciamento, com $98 \%$ de homologia com $D$. immitis (Gen Bank n. AJ537512-1). Nenhum dos animais havia sido submetido a tratamento profilático para CHD e não havia relatos de viagens para regiões litorâneas. Assim, o presente estudo reporta dois casos raros de infecção por D. immitis em área brasileira não endêmica para a doença.

PALAVRAS-CHAVE: Cão. Dirofilaria immitis. Microfilária. Nematódeo parasita. Técnicas moleculares.

\section{DIROFILARIOSIS CANINA EN UNA ZONA NO ENDÉMICA BRASILEÑA}

RESUMEN: La dirofilariosis canina (CHD) es una enfermedad transmitida por mosquitos y causada por Dirofilaria immitis. En este estudio, dos perros de edad adulta a anciano, de área no endémica presentaron signos clínicos de la enfermedad. El primero presentó lesiones en la piel, pérdida del apetito, debilidad, palidez de mucosas e hipertermia, mientras el otro presentó severa ascitis, anorexia e intolerancia al ejercicio, decúbito lateral, y soplos cardíacos acentuados. Ambos presentaron taquipnea, trombocitopenia, leucocitosis y microfilaremia. La investigación de D. immitis por multiplex-PCR (gen COI) resultó positivo en ambos casos, confirmados por la técnica de secuenciación, con $98 \%$ de homología con $D$. immitis (Gen Bank n.AJ537512-1). Ninguno de los animales había sido sometido al tratamiento profiláctico para CHD, y sin relatos de viajes a regiones costeras. El presente estudio reporta dos casos raros de la infección por D. immitis en zona no endémica de Brasil.

PALABRAS CLAVE: Dirofilaria immitis. Microfilaria. Nematodo parásita. Perro. Técnicas moleculares.

\section{Introduction}

Heartworms are nematodes belonging to the $D i$ rofilaria genus. Both $D$. immitis and D. repens species usually affect dogs, but $D$. immitis is the most important in veterinary medicine causing Canine Heartworm Disease (CHD) (CIUCA et al., 2016; SMOUT et al., 2016). It is a serious and potentially fatal disease in many regions of the world (MCCALL et al., 2008; BOWMAN; ATKINS, 2009; BORTHAKUR et al., 2016; MITERPAKOVA et al., 2016; SMOUT et al., 2016), including Brazil (OGAWA et al., 2013;
LABARTHE et al., 2014).

The occurrence of the disease is associated to the presence of mosquitoes, ie. Aedes spp., Anopheles spp. and Culex spp. Moreover, favorable climatic conditions as well as traffic between harmless and endemic regions also contribute to the increased number of cases (LABARTHE et al., 1997; DA SILVA; LANGONI, 2009; CIUCA et al., 2016). Intrinsic factors, ie. breed, age and sex, also appear to be related to the epidemiology of the disease in dogs (ALMEIDA et al., 2001; WANG et al., 2014). The parasite is distributed in temperate and tropical regions, especially in North Ame-

DOI: https://doi.org/10.25110/arqvet.v19i2.2016.5927

${ }^{1}$ Mississippi State University; College of Veterinary Medicine; Dept. Pathobiology and Population Medicine.

${ }^{2}$ Sao Paulo State University; School of Veterinary Medicine and Animal Science. Dept. Veterinary Clinics. 
rica (BOWMAN, 2010; TAYLOR et al., 2010; WANG et al., 2014). In Brazil, the higher prevalence is associated to the coastal areas (SOARES et al., 2014). However, the disease can be also related to no-coastal areas (OGAWA et al., 2013).

The diagnosis includes direct observation of circulating microfilariae and immunodiagnostic tests (BATISTA et al., 2008; CIUCA et al., 2016). Recently, molecular diagnosis, ie polymerase chain reaction (PCR), has been shown to provide important information mainly in non-endemic areas, in which immunodiagnostic tests may fail to detect the infected animals (TARELLO, 2001; RISHNIW et al., 2006; TAYLOR et al., 2010; CIUCA et al., 2016).

Different antihelmintics have been used to prevent and treat the infection focusing three different parasite stages (LABARTHE et al., 2015). CHD can usually be prevented by regular use of one of the available macrocyclic lactone (ML) preventives, ie. ivermectin, milbemycinoxime, moxidectin, selamectin (BLAGBURN et al., 2011; WOLSTENHOLME et al., 2015; BLAGBURN et al., 2016), and diethylcarbamazine (MCCALL et al., 2014), but multiple doses may be necessary for the protection. For the adulticide treatment, the dose varies with the amount of parasites (WOLSTENHOLME et al., 2015). Nowadays, it is usually performed with a combination of ivermectin and doxycycline (GRANDI et al., 2010; MAXWELL et al., 2014), or melarsomine dihydrochloride (KRAMER et al., 2011; MCHAFFIE, 2012). Cases with high parasite load should be treated with minimal doses to avoid mass death of adult parasites, which can cause vessel blockage. In these cases, the combination with ML preventive drugs is strongly recommended (KRAMER et al., 2011; MCCALL et al., 2014). In other hand, the microfilaricide treatment is recommended to prevent the spread of disease by eliminating the circulating microfilariae. Surgical resection of the parasite is also a possibility of treatment in some cases (TAYLOR et al., 2010).

D. immitis presents a high importance to public health, and considered a neglected zoonosis (DA SILVA; LANGONI, 2009; AMBILY; USHA, 2012). However, microfilaremia does not occur in humans (KLINGE et al., 2011) and, once at the heart, the larvae do not reach the sexual maturation and die. The dead parasites stop at the pulmonary artery on lung tissue, where usually form calcified pulmonary nodules, characterizing the human pulmonary dirofilariasis. The disease has a benign course. However, it may be misdiagnosed by image (radiology) as a primary or metastatic tumor (DAIPERT-GARCIA et al., 2004; KLINGE et al., 2011). Symptoms can vary: chest pain, cough, hemoptysis, sore throat, wheezing, chills, fever, fatigue, syncope, and weight loss (RODRIGUES-SILVA et al., 2004).

\section{Case report}

Two mature adult to senior dogs with complete annual vaccination program, no history of travel to coastal areas or prophylactic treatment to $\mathrm{CHD}$, presented acute CHD-related clinical signs and death. Both animals lived in Botucatu (22 53 '09'S; 48 26'42”W), 300km from São Paulo, SP, where the prevalence is $<1 \%$ (GUERRA et al., 2000). Both patients had blood samples collected by jugular venipuncture in EDTA and dry tubes and pleural effusion collected as described by thoracocentesis in EDTA and dry tubes.
All analysis was performed within an hour after collection.

Laboratorial analysis included complete blood count $(\mathrm{CBC})$ performed using an automated hematology analyzer (pocH-100iTM Sysmex, Brazil) and leukocyte differential count in at least 100 white blood cells in blood smears. Blood smears were stained with the Panotico Rapido kit (Laborclin, Brazil). The biochemical analysis included dosage of blood urea nitrogen (BUN), creatinine, alkaline phosphatase (ALP), gamma-glutamyltransferase (GGT) and alanine aminotransferase (ALT) by the use of commercial kits (Katal Intertek, Brazil). Pleural effusion was performed analyzing the chemical characteristics by Combur Test kit (Roche, Switzerland), density and protein concentration by refractometer and direct sediment slides. The total number of nucleate cells and red blood cell (RBC) contamination was counted by Neubauer chamber counting method as described by Weiser et al. (2012).

To confirm the identity of the microfilaria, a multiplex PCR was performed following the technique described by Latrofa et al. (2012). DNA was extracted directly from $330 \mu \mathrm{l}$ of each blood and pleural effusion sample using the Illustra Blood Genomic Prep Mini Spin Kit (GE ${ }^{\circledR}$, USA) and following the manufacturer's recommended protocol. DNA elution was performed with $100 \mu 1$ to increase the quantity of recovered DNA. The DNA was stored at $-20^{\circ} \mathrm{C}$ until PCR analysis. PCR products were previously purified using QIA quick PCR purification kit (Qiagen ${ }^{\circledR}$, USA). The purified products were directly sequenced using BigDye ${ }^{\circledR}$ Terminator v3.1 Cycle Sequencing Kit and Applied Biosystems 3500 Genetic Analyzers sequencer. The partial coxl gene sequences were compared using the Blast Genious program, which confirmed being $D$. immitis under the accession number AJ537512-1 in Gene Bank.

\section{Case 1}

An 8-years-old intact male Pinscher presenting skin lesions, loss of appetite, weakness and faint episodes for two weeks. Clinical evaluation showed pale mucosa membrane, hyperthermia $\left(41^{\circ} \mathrm{C}\right)$, tachypnea (42 breath/min) and 120 beats/min, without neurological alterations. Peripheral blood and pleural effusion were drawn during the clinical exam. The animal died at the same day but the owner did not authorize necropsy. Biochemical analysis indicated hepatocellular lesion $(\mathrm{ALT}=530.0 \mathrm{U} / \mathrm{L})$ and cholestasis $(\mathrm{ALP}=235.0$ $\mathrm{U} / \mathrm{L}$; GGT $=8.1 \mathrm{U} / \mathrm{L})$. The $\mathrm{CBC}$ showed a severe non-regenerative anemia $(\mathrm{Ht}$, hematocrit $=10 \%)$, thrombocytopenia $(95,000$ platelets $/ \mu \mathrm{L})$, and neutrophilic leukocytosis $(21,000$ leukocytes $/ \mu \mathrm{L}$ ) followed by monocytosis and eosinopenia. In addition, microfilaremia was observed in the blood smears by direct microscopic visualization (3-5 microfilariae per field, 100X amplification, Figure 1). Molecular analysis showed positivity to $D$. immitis. 
Figure 1: Microfilaria in the blood smear stained with the Panotico Rapido kit (100X amplification; Carl Zeiss ${ }^{\circledR}$ JENAMED 2 microscope, Germany).

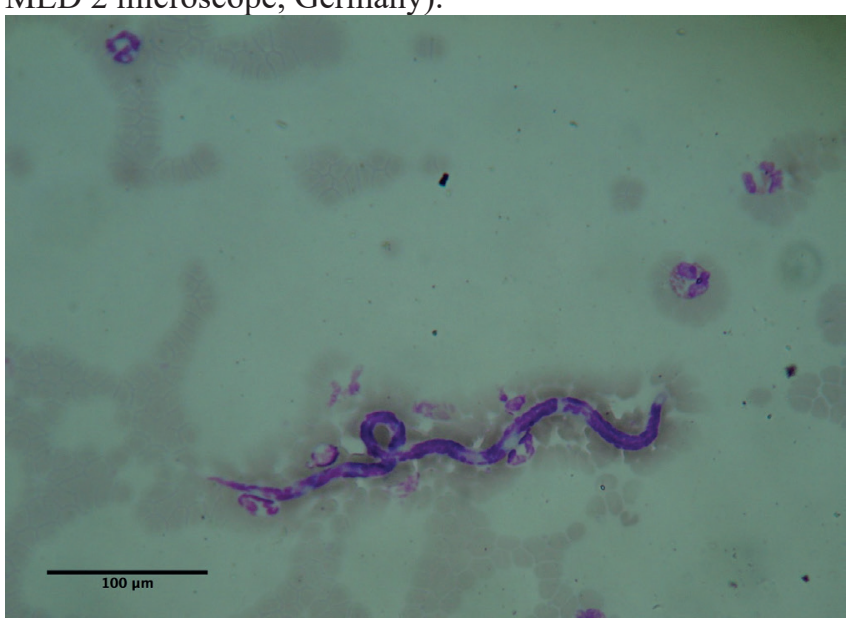

Case 2

The other case was a 7-years-old intact female Labrador. The animal was attended to the Veterinary Hospital with severe ascites, history of dyspnea, anorexia and exercise intolerance two days before. The dog presented lateral decumbency, tachypnea (65 breaths/min), tachycardia (140 beats/min) and marked heart murmurs at the clinical exam. CBC showed a mild non-regenerative anemia $(\mathrm{Ht}=34 \%)$ and thrombocytopenia $(60,000$ platelets/ $\mu \mathrm{L})$. Biochemical exam showed increased ALT (618 U/L), AST (1,200 U/L), creatinine $(5 \mathrm{mg} / \mathrm{dL})$ and blood urea nitrogen test $(\mathrm{BUN}=$ $350 \mathrm{mg} / \mathrm{dL}$ ). At X-ray visualization, thoracic region presented intense pleural effusion, opacification and increased right heart silhouette with lateral displacement of the cardiac apex. The pleural effusion had reddish color, turbidity, density of 1.036, positive coagulation, $\mathrm{pH} 8.0$, protein of $5.8 \mathrm{~g} / \mathrm{dL}$, fibrinogen of $100 \mathrm{mg} / \mathrm{dL}$, positive glucose, $\sim 2,205$ nucleated cells $/ \mu \mathrm{L}$ and $\sim 311,550 \mathrm{RBC} / \mu \mathrm{L}$. Typical small lymphocytes were predominant to the cytological exam, followed by segmented neutrophils and macrophages, erythrophagocytosis and leukophagocytosis, and one microfilaria was also observed. The effusion sample was positive for $D$. immitis by PCR. The animal received fluid therapy. Six liters of abdominal fluid were drained. The owner was requested to return in the next day by the veterinary to start the adulticide treatment, however, the dog died and did not return.

\section{Discussion}

In Brazil, although some studies have reported high frequencies in coastal areas, reports in remote coastal regions are also common (OGAWA et al., 2013; LABARTHE et al., 2014; SOARES et al., 2014). Souza and Larsson (2001) detected 6/154 (3.8\%) D. immitis-positive blood samples in São Paulo (capital of the State), and supports the present reports from Botucatu, located $300 \mathrm{~km}$ from the capital, where the prevalence of the parasite is less than 1\% (GUERRA et al., 2000). Meantime, in Brazilian coast regions the prevalence can be higher than 40\% (DANTAS-TORRES, 2008; SOARES et al., 2014).

In non-endemic areas, it is common the under diag- nosis of CHD, once the hosts may present low level of microfilaremia not enough for the detection by direct diagnosis, and low number of adult parasites, which may produce false-negative results on immunodiagnostic assays (SOARES et al., 2014; CIUCA et al., 2016). The under diagnosis may be a problem in dogs that have never received prophylactic treatment and/or are immunosuppressed. Usually older and senior dogs are more frequently diagnosed with dirofilariosis due to their lower effective immune response (ALMEIDA et al., 2001; WANG et al., 2014). Such information matches with our cases in which both dogs were mature adult to senior animals. Moreover, under diagnosed cases are also associated with reduced survival time. It probably happens because of the parasite's life cycle, in which clinical signs are observed only when the parasites reach the adult form and start to reproduce, resulting in acute cardiac disease and renal failure (VENCO et al., 2005; AMBILY; USHA, 2012). This was probably what happened with both reported cases in this study. The patients developed non-specific and mild clinical signs with fast progression in less than two weeks, which resulted in severe clinical pathological alterations and acute death due to cardiac failure.

During the asymptomatic or occult phase of the disease, microfilaremia is often low and parasites still migrate and grow (MAXWELL et al., 2014). Once adults, these parasites locate at the right atrium and ventricle, leading to pulmonary hypertension, myocardial hypertrophy and heart failure (ROCHA, 2010; MAXWELL et al., 2014). The atypical migration usually occurs when microfilariae occlude and rupture the small vessels, which releases the immature parasite in atypical places where they can mature, ie renal artery, aorta, left ventricle, left atrium, aortic lumen, internal iliac arteries, peritoneal cavity, testicular tissue and abscesses (DAIPERT-GARCIA et al., 2004; SEVIMLI et al., 2007; BRENER et al., 2012), similar to what probably happened with female Labrador in this study, who had microfilaria on pleural effusion.

Cases of massive infections, as the male Pinscher case, are common the development of severe circulatory and immune-mediated disorders. Obstruction of blood flow leads to congestive right heart failure and deposition of immune complex and fibrin in the glomeruli may lead to gromerulonephritis and renal failure. Congestive right heart failure often leads to increase of hepatic enzymes activity, as a secondary congestion and injury of the liver. In the same way, renal injury is highly associated with azotemia and decrease of urinary density at the refractometer. Both disorders are the most common causes of death in non-treated dirofilariasis (TAYLOR et al., 2010).

The clinical signs during microfilaremia often include persistent cough and dyspnea, loss of weight and exercise intolerance, observed on both cases. However, during the adult worms stage, ascites and hydrothorax can be also reported (RIBEIRO, 2004; ROCHA, 2010; MAXWELL et al., 2014).

Hematological and biochemical alterations observed in these dogs matched with the alterations described by Rocha (2010) and Polizopoulou et al. (2000), who observed thrombocytopenia, non-regenerative anemia, leukocytosis by neutrophilia, eosinophilia and basophilia, and increased ALT and creatinine. 
Eosinophilia and basophilia are commonly associated with allergic and parasitic infections, which the immune system recognizes the parasite antigen, leading to increase bone marrow production of these cells (LILLIEHOOK et al., 2000).

Anemia of inflammation is usually characterized by a mild to moderate non-regenerative anemia associated with neutrophilic leukocytosis, hypoferremia and increased storage of iron in tissues. This type of anemia is caused by multiple downstream effects of released cytokines, which shift the granulocytic cell production at bone marrow, decreasing erythroid production (GRIMES; FRY, 2015).

The chronic stress caused by the parasite can also lead to a leukogram of stress in which neutrophilia, lymphopenia, monocytosis and eosinopenia are observed (SCOTT, 2008). This pathological mechanism was probably the cause of the laboratorial alterations observed at the Case 1.

The most used diagnostic methods for CHD are the direct observation of circulating microfilariae and immunodiagnostic assays. Morphological diagnosis can be easily misdiagnosed with other filarial diseases. Furthermore, the detection of microfilaremia is not possible in the early stages of disease, or in the absence of female adult parasite. In addition, PCR is not yet wide used in the CHD diagnostic routine. PCR is more accurate than direct methods, but still relies on the microfilaremia. It is hard to misdiagnose $D$. immitis with other filarial diseases, but false-negative PCR results may occur during low microfilaremia, due to the lack of DNA to be detected. False-negative reactions seem to be prevalent in no or low-endemic areas (CIUCA et al., 2016). In this way, molecular methods, ie PCR, is still a good choice for screening and confirm the infection.

\section{Conclusions}

Circulatory alterations characterized both cases presented in this study confirmed by molecular methods. The presented results confirm the circulation of D. immitis in Botucatu area, since the animals did not present history of travel to coastal and non-endemic areas.

\section{Acknowledgements}

The authors thank the São Paulo State University for all the logistical support.

\section{Conflict of interest}

The authors declare that they have no competing interests.

\section{References}

ALMEIDA, M. A. O. et al. Parasitism of dogs with microfilarae of Dirofilaria immitis: influence of the breed, sex and age. Revista Brasileira de Saúde e Produção Animal, v. 2, n. 3, p. 59-64, 2001.

AMBILY, V. R.; USHA, N. P. Microfilariosis in dogs - an emerging cause for renal failure. International Journal of Science and Research, v. 3, n. 6, p. 1554-1556, 2012.
BATISTA, N. C. et al. Use of the commercial kit anigen rapid Dirofilaria immitis Ag® in comparison with the modified Knott technique for incidence in dogs with dirofilariosis. Acta Veterinaria Brasilica, v. 2, n. 3, p. 76$79,2008$.

BLAGBURN, B. L. et al. Efficacy of four commercially available heartworm preventive products against the JYD34 laboratory strain of Dirofilaria immitis. Parasites \& Vectors, v. 9, n. 1, p. 191, 2016.

BLAGBURN, B. L. et al. Comparative efficacy of four commercially available heartworm preventive products against the MP3 laboratory strain of Dirofilaria immitis. Veterinary Parasitology, v. 176, n. 2-3, p. 189-194, 2011.

BORTHAKUR, S. K. et al. Occult dirofilariosis in dogs of North Eastern Region in India. Journal of ArthropodBorne Diseases, v. 10, n. 1, p. 92-97, 2016.

BOWMAN, D. D. Georgis parasitologia veterinária. 9th. ed. Rio de Janeiro: Elsevier, 2010. 448 pp.

BOWMAN, D. D.; ATKINS, C. E. Heartworm biology, treatment, and control. The Veterinary Clinics of North America. Small Animal Practice, v. 39, n. 6, p. 1127-1158, 2009.

BRENER, B. et al. Ectopic dirofilariosis in two dogs from Rio de Janeiro state, Brazil. Revista do Instituto de Medicina Tropical de São Paulo, v. 54, n. 3, p. 175-177, 2012.

CIUCA, L. et al. Heat treatment of serum samples from stray dogs naturally exposed to Dirofilaria immitis and Dirofilaria repens in Romania. Veterinary Parasitology, v. 225, p. 81-85, 2016.

DA SILVA, R. C.; LANGONI, H. Dirofilariasis. Neglected emerging zoonosis. Ciência Rural, v. 39, n. 5, p. 1614$1623,2009$.

DAIPERT-GARCIA, D. et al. Utilização da PCR para diagnóstico específico da dirofilaríase pulmonar humana. Revista da Sociedade Brasileira de Medicina Tropical, v. 37, p. 444, 2004

DANTAS-TORRES, F. Canine vector-borne diseases in Brazil. Parasites \& Vectors, v. 1, n. 1, p. 25, 2008.

GRANDI, G. et al. A combination of doxycycline and ivermectin is adulticidal in dogs with naturally acquired heartworm disease (Dirofilaria immitis). Veterinary Parasitology, v. 169, n. 3-4, p. 347-351, 2010.

GRIMES, C. N.; FRY, M. M. Nonregenerative anemia: mechanisms of decreased or ineffective erythropoiesis. Veterinary Pathology, v. 52, n. 2, p. 298-311, 2015.

GUERRA, R. M. S. N. C. et al. Prevalence of microfilariae in dogs attended at the Veterinary Hospital of FMVZ- 
UNESP, Botucatu-SP. In: JORNADA PAULISTA DE PARASITOLOGIA, 13., 2000, Botucatu. Anais...Botucatu: FMVZ, 2000, p. 32.

KLINGE, M. E. S.; ROBAYO, P. C.; BARRETO, C. A. M. Dirofilaria immitis: a zoonoses present on a global level. Revista de Medicina Veterinária, v. 22, p. 57-68, 2011.

KRAMER, L. et al. Evaluation of lung pathology in Dirofilaria immitis-experimentally infected dogs treated with doxycycline or a combination of doxycycline and ivermectin before administration of melarsomine dihydrochloride. Veterinary Parasitology, v. 176, n. 4, p. 357-360, 2011.

LABARTHE, N. et al. Description of the occurrence of canine dirofilariasis in the State of Rio de Janeiro, Brazil. Memórias do Instituto Oswaldo Cruz, v. 92, n. 1, p. 47$51,1997$.

LABARTHE, N. V. et al. Updated canine infection rates for Dirofilaria immitis in areas of Brazil previously identified as having a high incidence of heartworm-infected dogs.

Parasites \& Vectors, v. 7, p. 493, 2014

LABARTHE, N. V. et al. Chemoprophylaxis of Dirofilaria immitis (Leidy 1856) infection at a high challenge environment. Parasites \& Vectors, v. 8, p. 523, 2015.

LATROFA, M. S. et al. A multiplex PCR for the simultaneous detection of species of filarioids infesting dogs. Acta Tropica, v. 122, n. 1, p. 150-154, 2012.

LILLIEHOOK, I. et al. Diseases associated with pronounced eosinophilia: a study of 105 dogs in Sweden. Journal of Small Animal Practice, v. 41, n. 6, p. 248-253, 2000

MAXWELL, E. et al. Outcome of a heartworm treatment protocol in dogs presenting to Louisiana State University from 2008 to 2011: 50 cases. Veterinary Parasitology, v. 206, n. 1-2, p. 71-77, 2014.

MCCALL, J. W. et al. Safety and efficacy of $10 \%$ imidacloprid $+2.5 \%$ moxidectin for the treatment of Dirofilaria immitis circulating microfilariae in experimentally infected dogs. Veterinary Parasitology, v 206, n. 1-2, p. 86-92, 2014

MCCALL, J. W. et al. Heartworm disease in animals and humans. Advances in Parasitology, v. 66, n., p. 193-285, 2008

MCHAFFIE, J. Dirofilaria immitis and Wolbachia pipientis: a thorough investigation of the symbiosis responsible for canine heartworm disease. Parasitology Research, v. 110, n. 2, p. 499-502, 2012.

MITERPAKOVA, M. et al. Canine dirofilariosis endemic in Central Europe-10 years of epidemiological study in Slovakia. Parasitology Research, v. 115, n. 6, p. 2389-
2395, 2016.

OGAWA, G. M. et al. Canine heartworm disease in Porto Velho: first record, distribution map and occurrence of positive mosquitoes. Revista Brasileira de Parasitologia Veterinaria, v. 22, n. 4, p. 559-564, 2013.

POLIZOPOULOU, Z. S. et al. Clinical and laboratory observations in 91 dogs infected with Dirofilaria immitis in northern Greece. The Veterinary Record, v. 146, n. 16, p. 466-469, 2000.

RIBEIRO, V. M. Control of canine and feline helminths. Revista Brasileira de Parasitologia Veterinaria, v. 13, n. S1, p. 88-95, 2004.

RISHNIW, M. et al. Discrimination between six species of canine microfilariae by a single polymerase chain reaction. Veterinary Parasitology, v. 135, n. 3-4, p. 303-314, 2006.

ROCHA, C. A. R. Dirofilaria immitis and canine dirofilariasis: a retrospective study. 2010. Dissertação (Mestrado em Medicina Veterinária) - Universidade de Trás-os-Montes e Alto Douro, Portugal, 2010.

RODRIGUES-SILVA, R. et al. Human pulmonary dirofilariasis at Rio de Janeiro, Brazil: a case report. Revista da Sociedade Brasileira de Medicina Tropical, v. 37, n. 1, p. 56-59, 2004.

SCOTT, M. A. Leukocytes. In: STOCKHAM, S. L.; SCOTT, M. A. (Eds.) Fundamentals of Veterinary Clinical Pathology. Ames, IA: Wiley-Blackwell, 2008, p. 53-106.

SEVIMLI, F. K. et al. Dirofilaria immitis infection in dogs: unusually located and unusual findings. Parasitology Research, v. 101, n. 6, p. 1487-1494, 2007.

SMOUT, F. A. et al. Dingoes (Canis dingo Meyer, 1793) continue to be an important reservoir host of Dirofilaria immitis in low density housing areas in Australia.

Veterinary Parasitology, v. 215, p. 6-10, 2016.

SOARES, H. S. et al. Survey of canine tick-borne diseases in Lábrea, Brazilian Amazon: 'accidental' findings of Dirofilaria immitis infection. Revista Brasileira de Parasitologia Veterinaria, v. 23, n. 4, p. 473-480, 2014.

SOUZA, N. F.; LARSSON, M. H. M. A. Frequency of canine heartworm disease (D. immitis) in some regions of São Paulo State using a circulating antigen indicator test. Arquivo Brasileiro de Medicina Veterinária e Zootecnia, v. 53, n. 3, p. 321-325, 2001.

TARELLO, W. Importance in the dog of concentration tests for the diagnosis of heartworm disease in non-endemic areas. Vet On-Line - The International Journal of Veterinary Medicine. Priory Medical Journals. Disponível em: <http://www.priory.com/vet/cardioworm.htm $>$. Acesso em: 18 aug. 2015. 
TAYLOR, M. A.; COOP, R. L.; WALL, R. L. Parasitologia veterinária. 3rd. ed. Rio de Janeiro: Guanabara-Koogan, 2010. $726 \mathrm{p}$.

VENCO, L.; KRAMER, L.; GENCHI, C. Heartworm disease in dogs: unusual clinical cases. Veterinary

Parasitology, v. 133, n. 2-3, p. 207-218, 2005.

WANG, D. et al. Factors influencing U.S. canine heartworm (Dirofilaria immitis) prevalence. Parasites \& Vectors, v. 7 , p. 264, 2014.

WEISER, G.; ALLISON, R.; JENSEN, W. A. General principles of laboratory testing and diagnosis, In: THRALL, M. A. et al. (Eds.) Veterinary Hematology and Clinical

Chemistry. Ames, IA: Wiley-Blackwell, 2012, pp. 3-58.

WOLSTENHOLME, A. J. et al. The emergence of macrocyclic lactone resistance in the canine heartworm, Dirofilaria immitis. Parasitology, v. 142, n. 10, p. 12491259, 2015. 